\title{
Teaching Video NeuroImage: Clenched Fists as an Unusual Presentation of Focal Neuromyotonia
}

Roshan Dhanapalaratnam, MMed, MBBS, Raymond Schwartz, PhD, MBBS, and William Huynh, PhD, MBBS, BSc Neurology ${ }^{\circledR}$ 2021;97:e429-e430. doi:10.1212/WNL.0000000000012055

Figure 1 Active Finger Extension From the Resting Clenched Fist State



(A-C) Remarkably delayed and incomplete relaxation (pseudomyotonia) of forearm wrist/finger flexors before treatment, taking approximately 12 seconds to complete the maneuver. (D, E) Significant improvement to 4 seconds following treatment observed in both hands; only left hand shown.

A 72-year-old woman with a history of asthma and bronchiectasis presented with a 7-year history of bilateral hand cramps, initially affecting the right, frequently resulting in clenched fists. Examination revealed clenched fists bilaterally in the resting state and pseudomyotonia with incomplete relaxation following active finger extension (figure $1, \mathrm{~A}-\mathrm{C}$; video 1 ). Myokymia and percussion myotonia were not observed. No weakness was elicited in the muscles. Needle EMG of the forearm flexors demonstrated bursts of spontaneous high-frequency waning discharges typical of neuromyotonia (figure 2; video 2). Significant clinical improvement was observed following treatment with botulinum toxin injections and oxcarbazepine (figure 1, D-F).

\author{
Correspondence \\ Dr. Huynh \\ william.huynh@ \\ sydney.edu.au
}

\section{MORE ONLINE}

Videos

\section{Teaching slides}

links.lww.com/WNL/

B378

From the Prince of Wales Clinical School (R.D., W.H.), The University of New South Wales; Southern Neurology (R.S., W.H.), Kogarah; and Mind Centre (W.H.), The University of Sydney, Australia.

Go to Neurology.org/N for full disclosures. Funding information and disclosures deemed relevant by the authors, if any, are provided at the end of the article. 
Figure 2 Neuromyotonic Discharges

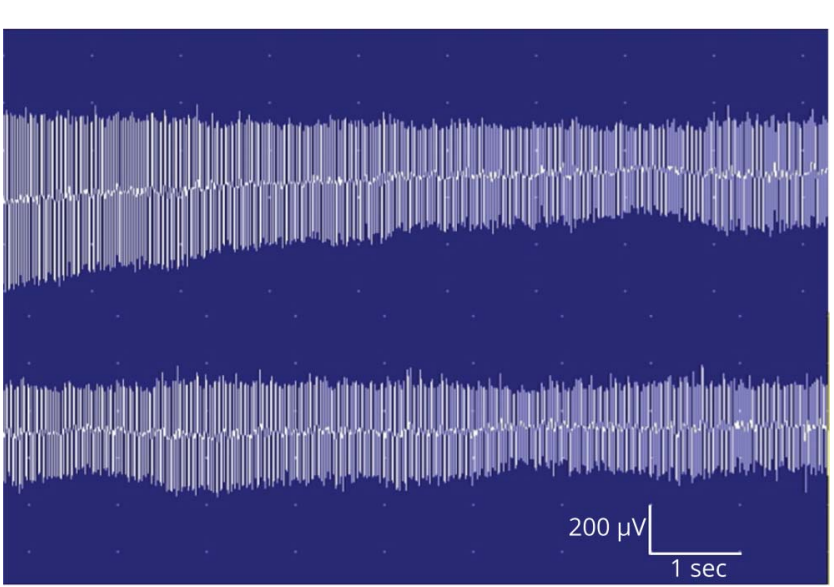

Spontaneous bursts of high-frequency (120-180 Hz) waning amplitude discharges on needle EMG of flexor carpi ulnaris muscle.

The current case illustrates an unusual but treatable presentation of the rare focal form of neuromyotonia, ${ }^{1,2}$ and should be differentiated from other conditions that may have similar presentations such as myotonic dystrophy and other nondystrophic myotonias, ulnar neuropathies, and Dupuytren contracture, the latter of which may result in unnecessary surgical intervention. As with the current case, patients previously reported with this condition tend to be older women with a history of chronic obstructive pulmonary disease (COPD) managed by inhaled $\beta 2$ sympathomimetics. Whereas the pathomechanisms remain elusive, enhanced axonal hyperexcitability secondary to COPDinduced hypoxemia as well as hyperpolarization from sympathomimetics, through their effects on voltage-gated $\mathrm{Na}+/$ $\mathrm{K}+$ pumps, may result in ectopic firing in high-frequency bursts. ${ }^{1,2}$ Other cases have also been found in association with a more generalized voltage-gated potassium channel antibody autoimmunity, ${ }^{3}$ although these antibodies were absent in the current case.

\section{Study Funding}

No targeted funding reported.

\section{Disclosure}

The authors report no disclosures relevant to the manuscript. Go to Neurology.org/N for full disclosures.

Appendix Authors

\begin{tabular}{lll}
\hline Name & Location & Contribution \\
\hline $\begin{array}{l}\text { Roshan } \\
\text { Dhanapalaratnam, } \\
\text { MBBS }\end{array}$ & $\begin{array}{l}\text { Institute of Neurologic } \\
\text { Sciences, Prince of Wales } \\
\text { Hospital }\end{array}$ & $\begin{array}{l}\text { Designed and } \\
\text { conceptualized } \\
\text { manuscript, drafted } \\
\text { manuscript }\end{array}$ \\
\hline $\begin{array}{l}\text { Raymond } \\
\text { Schwartz, PhD, } \\
\text { MBBS }\end{array}$ & $\begin{array}{l}\text { Southern Neurology, } \\
\text { Kogarah; Sydney }\end{array}$ & $\begin{array}{l}\text { Patient management, } \\
\text { final edit of manuscript }\end{array}$ \\
\hline $\begin{array}{l}\text { William Huynh, } \\
\text { PhD, MBBS, BSc }\end{array}$ & $\begin{array}{l}\text { Brain and Mind Centre, } \\
\text { University of Sydney; } \\
\text { Southern Neurology, } \\
\text { Kogarah, Australia }\end{array}$ & $\begin{array}{l}\text { Design and } \\
\text { conceptualized } \\
\text { manuscript, patient } \\
\text { management, drafted } \\
\text { and final edit of the }\end{array}$ \\
& & $\begin{array}{l}\text { manuscript } \\
\end{array}$ \\
\hline
\end{tabular}

\section{References}

1. Modarres H, Samuel M, Schon F. Isolated finger flexion: a novel form of focal neuromyotonia. J Neurol Neurosurg Psychiatry. 2000;69:110-113.

2. Gantenbein AR, Wiederkehr M, Meuli-Simmen C, Schwegler G. Focal neuromyotonia: do I love you? J Neurol. 2010;257:1727-1729.

3. Lopez Chiriboga AS, Matsumoto J, Sorenson E, Klein CJ, McKeon A. Teaching Video NeuroImages: acquired focal neuromyotonia in LGI-1 autoimmunity. Neurology. 2018;90:e1636-e1637. 


\section{Neurology}

\section{Teaching Video NeuroImage: Clenched Fists as an Unusual Presentation of Focal Neuromyotonia}

Roshan Dhanapalaratnam, Raymond Schwartz and William Huynh

Neurology 2021;97;e429-e430 Published Online before print April 26, 2021

DOI 10.1212/WNL.0000000000012055

This information is current as of April 26, 2021

\section{Updated Information \&} Services

References

Subspecialty Collections

Permissions \& Licensing

Reprints including high resolution figures, can be found at: http://n.neurology.org/content/97/4/e429.full

This article cites 3 articles, 2 of which you can access for free at: http://n.neurology.org/content/97/4/e429.full\#ref-list-1

This article, along with others on similar topics, appears in the following collection(s):

All Clinical Neurology

http://n.neurology.org/cgi/collection/all_clinical_neurology

Botulinum toxin

http://n.neurology.org/cgi/collection/botulinum_toxin

EMG

http://n.neurology.org/cgi/collection/emg

Peripheral neuropathy

http://n.neurology.org/cgi/collection/peripheral_neuropathy

Information about reproducing this article in parts (figures,tables) or in its entirety can be found online at:

http://www.neurology.org/about/about_the_journal\#permissions

Information about ordering reprints can be found online:

http://n.neurology.org/subscribers/advertise

Neurology ${ }^{\circledR}$ is the official journal of the American Academy of Neurology. Published continuously since 1951, it is now a weekly with 48 issues per year. Copyright @ 2021 American Academy of Neurology. All rights reserved. Print ISSN: 0028-3878. Online ISSN: 1526-632X.

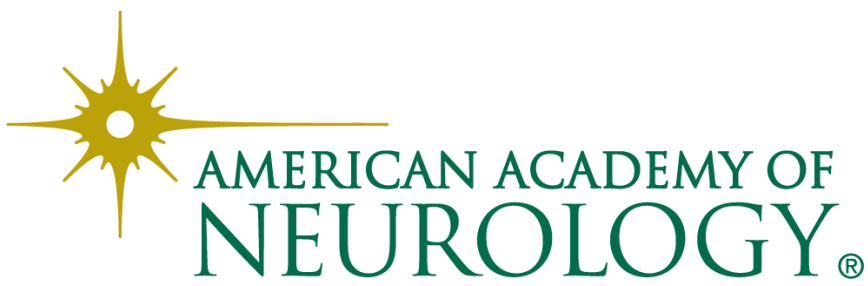

